\title{
The Occurrence of Thermophilic Campylobacter in Mink and an Experimental Oral Infection of Pregnant Mink by Campylobacter jejuni
}

\author{
By M. L. Hänninen, T. Ekman, T. Saranpää and M. Valtonen
}

\begin{abstract}
Hänninen, M. L., T. Ekman, T. Saranpää and M. Valtonen: The occurrence of thermophilic Campylobacter in mink and an experimental oral infection of pregnant mink by Campylobacter jejuni. Acta vet. scand. 1988, 29, 463-468. - The occurrence of $C$. jejuni in the intestinal contents of mink and in the mink feed, prepared from fresh, untreated slaughter offal, was studied. The farms and the central feeding kichens, from where the intestinal and feed samples were collected, were situated in the northwestern part of Finland. All mink samples, originating from 9 farms, and feed samples, originating from 2 central feeding kichens were negative for $C$. jejuni and for $C$. coli. The only positive faecal samples were obtained from a farm, being located in the southern part of Finland.

Experimental colonization of $C$. jejuni was followed in 10 pregnant mink during their last trimester of pregnancy. The animals colonized only transiently with C. jejuni. Five of the animals shedded campylobacters only for 1-2 weeks after inoculation. Two experimental animals aborted. These animals were colonized at the time of abortion with $C$. jejuni. The association of $C$. jejuni infection to abortion was not, however, confirmed. The uterine contents or the fetuses examined were negative for campylobacters.
\end{abstract}

feed; faeces; colonization; abortion.

\section{Introduction}

Campylobacter jejuni and C. coli can colonize the intestines of many wild and domestic animal species (Skirrow \& Benjamin 1984). The colonization of the intestinal tract starts soon after birth, although immunological factors in the maternal milk (Hassan \& Dolby 1985) or the faecal flora of adult animals may prevent colonization (Soerjadi et al. 1982). According to some authors, older animals are colonization-resistant to C. jejuni (Field et al. 1982). In one experiment neonatal mice, rats and rabbits colonized $C$.jejuni mainly in the caecum and colon, only during the first 2-3 weeks of life (Field et al. 1981).

Mink are not often shown to be infected with $C$. jejuni or other thermophilic campylobacters (Prescott \& Bruin-Mosch 1981), although the raw material for their feed consists of slaughter offal from swine, poultry etc., which is probably contamined by campylobacters. In 1982 an abortion epidemic, in which $C$. jejuni was suspected as the etiological agent, was reported on a mink farm in Canada. On the same farm $29 \%$ of mink failed to conceive, C.jejuni was isolated from the liver of the fetuses and from the 
placenta, uterus and spleen of the females (Hunter et al. 1983).

The present study was performed in order to obtain information on the occurrence of campylobacters in the intestinal contents of mink and mink feed. The possible abortifacient effect of $C$. jejuni on mink was studied by means of an experimental oral infection of pregnant minks with $C$. jejuni.

\section{Materials and methods}

\section{Intestinal and faecal samples}

Fresh intestinal scrapings from the jejunum, taken during the slaughter of mink in autumn 1984, were transported in Siff-agar (Sandven et al. 1982) and cultivated for C. jejuni and C.coli. The transport of the samples prior to cultivation did not take longer than $24 \mathrm{~h}$. A total of 80 samples were taken, from 8 farms in Northwest Finland which were supplied with feed by 2 different central feeding units.

In june 1985, 33 fresh faecal samples were taken at a farm located in the same district as those mentioned above. The samples were stored, cooled in plastic bags and cultivated for campylobacters $18 \mathrm{~h}$ later.

The intestinal scraping samples were cultivated both directly on the Blaser-Wang medium (Blaser et al. 1978) and enriched for 24 $\mathrm{h}$ in brucella-broth with FPB-supplement $\left(\mathrm{FeSO}_{4} \times 7 \mathrm{H}_{2} \mathrm{O}\right.$, sodium metabisulphite, sodium pyruvate, each at concentration of $0.05 \%$ ) and the same antimicrobial agents as in the Blaser-Wang medium for $24 \mathrm{~h}$ at $42 \%$. One loopful of the enrichment broth was then cultivated on Blaser-Wang medium. The faecal samples were likewise cultivated on Blaser-Wang medium. Suspected colonies were identified by Gram stain and biotyping (Skirrow \& Benjamin 1981). All incubations were made microaerophilically.

\section{Feed samples}

36 feed samples containing both swine and cattle offal, were taken from the same 2 central feeding units discussed above. The raw material samples were fresh and unfrozen. A $10 \mathrm{~g}$ sample was enriched with $90 \mathrm{ml}$ of the selective enrichment broth described above and cultivated after incubation of 24 $\mathrm{h}$ onto the selective medium of Blaser-Wang, which was incubated microaerophilically at $42^{\circ} \mathrm{C}$ for $48 \mathrm{~h}$.

\section{Experimental infection of pregnant mink}

Ten pregnant mink in the last trimester of the pregnancy were orally infected via the feed with a $C$. jejuni biotype 1 strain. The $C$. jejuni strain used was originally isolated from a sick child. After isolation the strain was stored in brucella broth with FPB supplement at $-70^{\circ} \mathrm{C}$. before use as an experimental strain it was subjected to 1 intragastric passage in adult mouse to obtain the natural infectivity of the strain. The strain grown for 2 days at $37^{\circ} \mathrm{C}$ in brucella broth with $5 \%$ sterile calf blood, was added to a small amount of feed on the cage nettings. The inoculum level was about $10^{8} \mathrm{CFU}$ (colony forming units) per animal. The animals were fasted for 1 day before the experimental infection. After inoculation the animals were observed daily for diarrhoea, abortion and other clinical symptoms. Faecal samples were taken periodically during May 1985. Faecal samples were either cultivated directly on Blaser-Wang medium or $1 \mathrm{~g}$ sample was diluted serially $(1: 10)$ in 0.1 $\%$ peptone water and quantitative counts were made on Blaser-Wang medium.

Before the infection experiment faecal samples were taken from the experimental animals and from 10 other minks at the farm and cultivated for campylobacters. Twenty more samples of individual animals were randomly taken at the same farm later in May and 40 at the end of September; these 
samples too were cultivated for campylobacters.

\section{Results}

No campylobacters were isolated from the 80 intestinal scraping samples, the 33 faecal samples or the 36 feed samples taken in the northwestern part of Finland. At the farm used for the experimental infection, 12 animals out of the 63 examined shedded $C$. jejuni biotype 1 in their faecal samples in May or September 1985. Two of the pregnant experimental animals also had $C$. jejuni biotype 1 in their faecal samples prior to the experimental infection.

The colonization of pregnant mink with C. jejuni was followed by direct qualitative cultivation and quantitatively by counting the CFU's of faecal samples at selected intervals. The results of qualitative cultivations are presented in Table 1 and the $\log _{10}$ of CFU's for 5 animals in Fig. 1. All experimental animals colonized with $C$. jejuni, but the colonization was transient. Five animals shedded campylobacters only for a few days, up to 2 weeks after infection. None of the experimental animals were shedding campylobacters on September 24. Then however, 6 other animals of the 34 examined shedded C. jejuni in their faecal samples.

Fig. 1 also shows that the counts of $C$. jejuni in the faecal samples of 3 animals declined rapidly. animal no. 6 did not eat on April 29 ; it had blood on the cage nettings and abortion was suspected. Later it did not have any offspring. The quantitative cultivation of faecal samples of this animal showed shedding of $1 \times 10^{5}-7 \times 10^{5} \mathrm{CFU} C$. jejuni/g during the last 12 days of the experiment. Animal no. 7 had similar symptoms as animal no. 6 on May 6 . The animal shed$\operatorname{ded} 3 \times 10^{4} \mathrm{CFU} C$. jejuni/g on May 6 and 7 $\times 10^{7} \mathrm{CFU} C$. jejuni/g on May 9. At May 10 it was killed for examination. Resorbed fe-

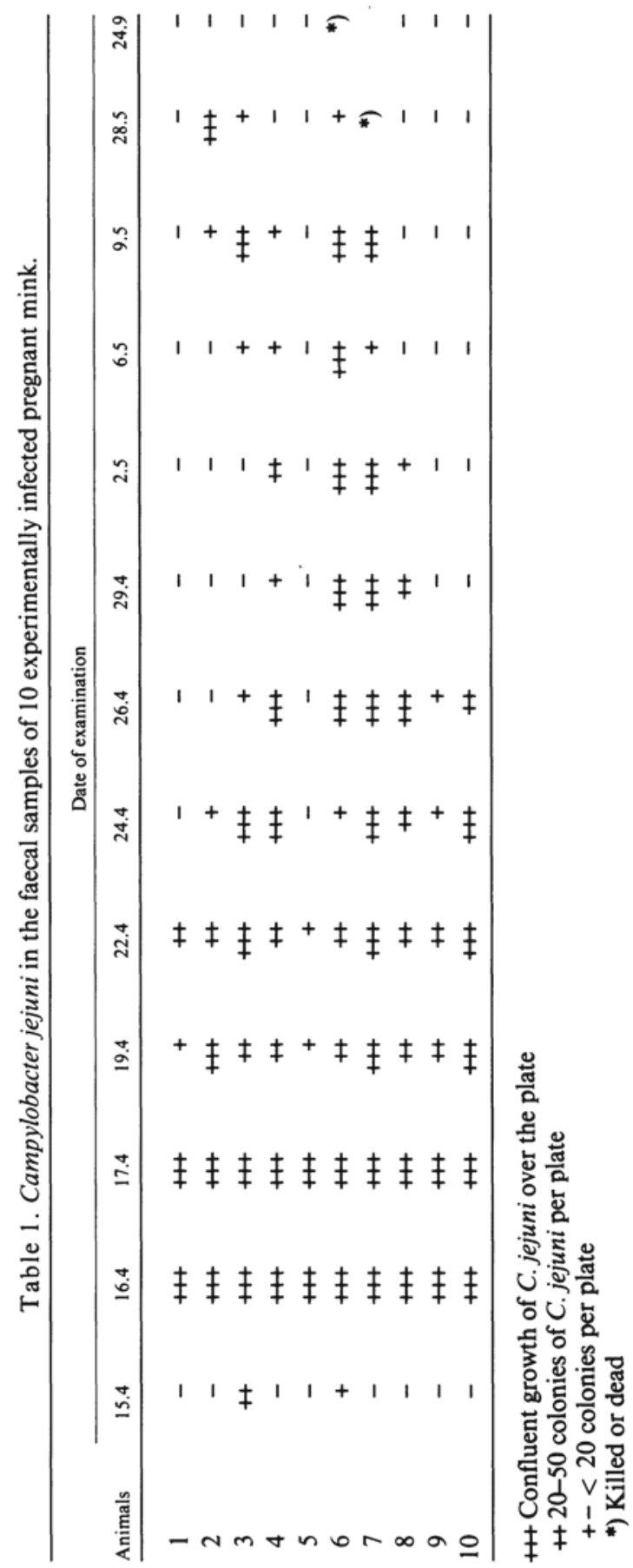

Acta vet. scand. vol. 29 no. $3-4$ - 1988 


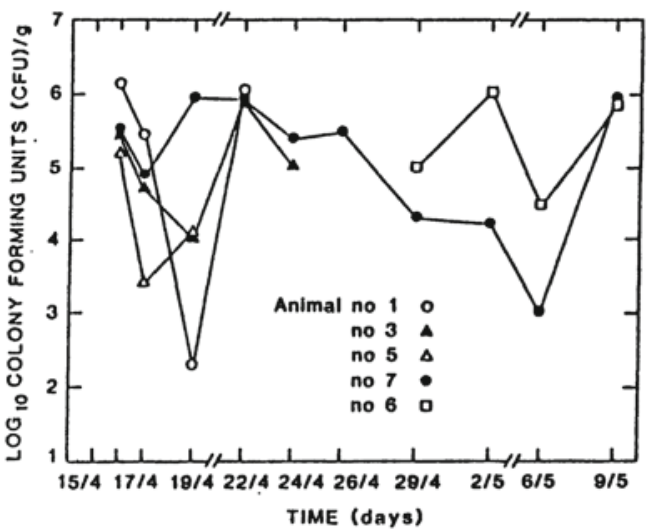

Figure 1. CFU/g of Campylobacter jejuni in the feacal samples of 5 experimentally infected (15.04) pregnant mink. Animal no. 1: 7/5, 7 whelps; animal no. 3: 6/5, 4 whelps; animal no. 5: $3 / 5,6$ whelps; animal no. 7: $6 / 5$ blood on the gage nettings; animal no. 7: 29/4 blood on the gage nettings.

tuses were found in the both corni uteri. No C. jejuni was isolated, however, in the intrauterinal fluid, in the liver or in the spleen of the animal. Other animals in the experimental group did not have any clinical symptoms. the number of offspring in the experimental group, 4.6 per female, was similar to that for the farm as a whole, 4.5 per female. In $198511.8 \%$ of the females in the farm either did not conceive, aborted or lost their offspring.

\section{Discussion}

Mink in Finland are usually farmed outdoors in open cages. The feed is thus easily contaminated by faecal contents of wild birds or rodents. The raw material of the feed often consists of slaughter offal, which is usually not heat treated. The fresh feed prepared of slaughter offal may thus be contaminated with many potentially enteropathogenic micro-organisms; e.g. in the USA (Turner \& Howell 1969) and in Germany
(Wenzell \& Keil 1980) feed-borne diseases are considered to be the main group of mink diseases, as confirmed by symptoms, pathological studies, bacteriological studies and response to antimicrobial agents. As campylobacters occur very often in the intestinal contents of slaughter animals, it is highly likely that the fresh mink feed prepared of slaughter offal will contain campylobacters. Swine populations are known to be widely infected with C. coli (Rosef 1981, Hänninen \& Raevuori 1981) and poultry also has been shown to be contaminated by $C$.jejuni (Hänninen \& Raevuori 1981). The infection rate of cattle is much lower (Prescott \& Bruin-Mosch 1981, Hänninen \& Raevuori 1981). The present study did not show any evidence of Campylobacter contamination of the mink feed. Ready-mixed mink feed made from slaughter offal has very high counts of contaminating flora (Poulsen \& Hansen 1978, Juokslahti 1978), and competing micro-organisms will thus prevent the survival of campylobacters in the feed. The negative faecal and intestinal samples obtained on all 11 farms provide further evidence that mink feed is not very often contaminated with campylobacters.

The raw material of the feed at the farm where $C$.jejuni was permanently isolated consisted of $50 \%$ fresh lungs and forestomach of cattle. The negative cultivation results at 9 farms and the positive samples obtained at 1 farm appears to be similar situation to that reported e.g. in the case of poultry farming, where many feeding units are heavily contaminated with $C$.jejuni, while some units are very clean. Prescott \& Bruin-Mosch (1981) in Canada likewise did not find $C$.jejuni in mink they examined. The quantitative cultivations in the present study showed that at least adult minks may normally be colonization resistant to $C$.jejuni, as the CFU of $C$. jejuni declined rapid- 
ly after inoculation. Three of the experimentally infected animals remained infected for the whole 6 weeks period, but by September the samples from all the animals were negative. The size of the experimental group, however, was too small for more definite conclusions on the colonization of mink with $C$. jejuni.

Two of the experimental animals aborted during the experiment. C. jejuni, however, could not be confirmed conclusively as the etiologic agent. Bacteriological cultivation showed no campylobacters in the intrauterine fluid or in the liver or spleen of the animals. The cultivations, however, were performed 4 days after the blood was on the cage nettings and the animal went off its feed, so that the bacteremia might already be over. In the intestinal samples, however, this animal showed $C$.jejuni counts of about $10^{3} / \mathrm{g}$ in the jejunal contents and about $10^{4}$ in the colonic contents.

\section{Acknowledgement}

The work was supported by a grant from the Finnish Association for Fur Animals.

\section{References}

Blaser MJ, Cravens J, Powers BW, Wang WL: Campylobacter enteritis associated with canine infection. Lancet 1978, II, 979-981.

Field LH, Underwood JL, Berry LJ: Intestinal colonization of neonatal animals by Campylobacter fetus subsp. jejuni. Infect. Immun. 1981, 31, 783-791.

Field LH, Underwood JL: Colonization of the digestive tract of adult mice with Campylobacter fetus subsp. jejuni. Abst. Ann. Meet. Amer. Soc. Microbiol. 1982, p. 209.

Hassan AG, Dolby JM: Mechanisms of protection of infant mice against colonisation by Campylobacter jejuni. In: Pearson AD, Skirrow MB, Lior H, Rowe B (eds.). Campylobacter III. Proc. 3rd International Workshop on Campylobacter infections, Ottawa, 7.-10. July 1985. PHLS London 1985, p. 126.
Hunter DB, Prescott JF, Pettit JR, Show WE: Campylobacter jejuni as a cause of abortion in mink. Can. vet. J. 1983, 24, 398-399.

Hunter DB, Prescott JF: Natural and experimental campylobacter diarrhoea in mink. Scientifur 1985, 9, 57-58.

Hänninen ML, Raevuori M: Occurrence of Campylobacter fetus subsp. fetus and Yersinia entecolitica in domestic animals and in some foods of animal origin. Nord. Vet.-Med. 1981, $33,441-445$.

Juokslahti T: Bacteriological quality of readymixed mink feed in Finland. Acta vet. scand. 1978, 19, 520-534.

Poulsen H, Hansen M: Bakterier og deres opførsel i minkfoder. (The bacteria of minkfeed). Dansk Pelsdyravl 1975, 38, 130-141.

Prescott JF, Bruin-Mosch CW: Carriage of Campylobacter jejuni in healthy and diarrhetic animals. Amer. J. vet. Res. 1981, 42, 164-165.

Rosef O: Campylobacter fetus subsp. jejuni som overflate kontaminant på nyslaktade og kjolte griseslakt. (Campylobacter fetus subsp. jejuni as acontaminant on fresh and chilled swine carcasses). Nord. Vet.-Med. 1981, 33, 535538.

Sandven $P$, Solberg $O$, Odegaard $K$, Myhre G: Improved medium for the transportation of gonococcal specimens. Acta pathol. microbiol. scand. Sect. B 1982, 90, 73-77.

Skirrow MB, Benjamin J: The classification of thermophilic campylobacters and their distribution in man and domestic animals. In: Newell DG (ed.): Campylobacter: epidemiology, pathogenesis and biochemistry. MTP Press Ltd. Boston 1984, pp. 40-44.

Soerjadi AS, Snoeyenbos GH, Weirback O: Intestinal colonization and competive exclusion of Campylobacter fetus subsp. jejuni in young chicks. Avian Dis. 1982, 26, 520-524.

Turner DG, Howell R: Bacteria and mink. Amer. Fur. Breed. July 1969, 13-14.

Wenzell UD, Keil H: Some aspects concerning the control of metabolism in ranch in the GDR. A contribution to the reduction of losses due to metabolic disturbances. Proc. 2nd Int. Sci. Congr. Fur Anim. Prod., Vedbæk, Danmark 1980, no. 24, 1-4. 


\section{Sammanfattning}

Förekomsten av termofila campylobakterier hos mink och en experimentel oral infektion av dräktiga minkar med campylobacter jejuni.

Tillsammans 186 fekala prov från tio finska minkfarmer odlades för $C$. jejuni och $C$. coli under hösten 1984 och år 1985. Campylobacter kunde isolerats i fekala prov från en farm som var belägen $\mathrm{i}$ Södra Finland. Andra farmer var belägna i Österbotten. 36 foderprov från två österbotniska centralfoderkök undersöktes också för Campylobac- ter. De undersökta foderprovena innehöll obehandlat svin-, nöt- och fjäderfäslaktavfall. I inget av foderprovena kunde Campylobacter isoleras.

Tio dräktiga minkar infekterades oralt med C. jejuni under den sista dräktigentstrimestern. Alla inokulerade minkar var koloniserade med Campylobacter för några veckor. Två av dessa djur aborterade. En association mellan Campylobacter-infektion och aborterna kunde inte konfirmeras.

(Received April 15, 1988).

Reprints may be requested from: Marja-Liisa Hänninen, College of Veterinary Medicine, Department of Food and Environmental Hygiene, Hämeentie 57, SF-00550 Helsinki, Finland. 